$\mathrm{PhD}$ (Pedagogy), Docent of the chair of Preschool Education, Kyiv Borys Grinchenko University, 18/2 Bulvarno-Kudriavska Str, Kyiv, Ukraine, 04053, o.kovalenko@kubg.edu.ua

Olena Litichenko ORCID: 0000-0002-7004-3837

$\mathrm{PhD}$ (Pedagogy), senior lecturer of the Department of Pedagogical Institute, Kyiv Borys Grinchenko University, 18/2 Bulvarno-Kudriavska Str, Kyiv, Ukraine, 04053, o.litichenko@kubg.edu.ua

\title{
PROVIDING EARLY CHILDHOOD EDUCATION WITH PROGRAMS: UKRAINIAN AND EUROPEAN EXPERIENCE
}

The article presents the results of theoretical study of normative documents of early childhood education of Ukraine and European Union countries; the opinion of authoritative scientists on the issue of providing early childhood education of Ukraine is examined. Attention is focused on the fact that the qualitative development of preschool children depends on the ability of teachers to ensure the individual development of each child, so the issue of creating a quality education program is especially relevant. Based on the analysis of discussion issues related to the providing early childhood educational institutions with programs, an empirical study of the awareness of preschool teachers and practitioners with the variety of educational programs for preschool institutions in Ukraine, their right to choose and create their own. Experience of Bulgaria, Lithuania, Great Britain, Switzerland is considered. The results of the analysis of state standards and programs for preschool education shows that there are common views on the education of preschool children in the European education.

In this article, the authors prove the importance and necessity opportunity for teachers to create their own programs for the development of preschool children.

Key words: early childhood education; state standarts for early childhood education; programs for early childhood educational institutions; development programs for preschool children; comprehensive programs; partial programs; program selection.

(C) Kovalenko Olena, Litichenko Olena, 2021 
https://doi.org/10.28925/2312-5829.2021.2.15

Introduction. Globalization processes in education at the beginning of the 21st century, the rapid development of society leads to mutual recognition, interpenetration and interaction at all levels of coexistence in the world. The study and analysis of the European educational experience and the extrapolation of its best models into the first link of the system of education in Ukraine is an urgent need of time.

Today, schools, preschool educational institutions, their principles and staff seek to find their own faces, work styles. At last there are certain conditions for it: teachers have the right to choose the methods and means of organizing the educational process with children. In addition, teaching staffs have emerged that bring to life the ideas of educators of the past and present. They make their statutes based on the concepts of these educators and other innovations. In this regard, the problem of concession the right for early childhood teachers to choose and create their own author programs for the organization of the educational process is becoming more relevant.

Purpose of the Study. Development programs for preschool children in Ukraine reflect government policies and social order for children's education. During European integration processes, the early childhood education of European countries is of great interest. Therefore, the objectives of our study were to study the researches of scientists on the problems of development and use of programs for early childhood educational institutions, the analysis of regulatory documents governing the issue, to analyze the experience of using programs for the development of preschool children in European countries, to formulate our vision for programs for preschool educational institutions (Shynkar, Bielienka, Kovalenko, 2020).

Research Methods. According to the objective, a theoretical and practical research was conducted. Theoretical study was conducted in two stages. The first stage included the analysis of scientific works of reputable scientists of Ukraine dealing with problems of early childhood education, the second - the study of legislative and normative base of the research. 
To accomplish these tasks, we have used such research methods as: observing the organization of the educational process in preschool institutions using various educational programs; observing the organization of methodological work with teachers on the use of different educational programs; selective interviews with principals, methodologists and early childhood teachers; questionnaire survey of preschool teachers. We conducted an interview using the Google form. 10 principals, 10 methodologists, 50 teachers from early childhood educational institutions in the communal property of Kyiv took part in the research.

On the first stage, the purpose of our study was to familiarize with the publications of scholars and practitioners on the problem of program selection in Ukraine. It should be noted that this problem is among the most urgent today. It has been widely discussed in the scientific community and in the mass media. These are the publications of H. Bielienka, A. Bohush, O. Dolynna, O. Kononko, O. Kovalenko, K. Krutii, V. Kuzmenko, Z. Plohii, T. Ponimanska, O. Proskura, T. Pyrozhenko and others.

According to Ukrainian scientists, the development of a regulatory framework for the functioning of early childhood educational institutions, the definition of educational standards, educational programs, scientific and methodological support of early childhood education is a significant factor in its quality (Vaskivska, Palamar, Kondratiuk, Zhelanova, 2018). In particular, T. Pirozhenko believes that the possibility of choice is the basis for the development of progressive educational changes, which makes it possible to support the movement forward and be competitive in the further path of self-realization of a person. Specialists in early childhood education adhere to their positions - there can be no one model program (Pirozhenko, 2018).

We fully share O. Kovalenko view that the right and ability to choose is a significant sign of democracy and a psycho-pedagogical culture, and that personality begins with choice (Bielienka, Kovalenko, Shynkar, 2020).

The content of the second stage of the theoretical study was the elaboration of regulatory documents that cover issues of providing early childhood education.

This issue was reflected in such documents as: the State National Program Osvita (Education: Ukraine of the 21st century), the Laws of Ukraine "On Education and "On 
Early Childhood Education", the Regulations on Early Childhood Education, the Exemplary Statute of an Early Childhood Educational Institution, a number of orders and instructional and methodological guidelines letters of the Ministry of Education and Science of Ukraine.

Thus, the State National Program Osvita (Education: Ukraine of the 21st century) states that one of the main ways of reforming early childhood education is developing state and authorial early childhood education programs. This position has been realized over the last few years.

The next document we worked on was the "Basic Component of Early Childhood Education" (Базовий компонент дошкільної освіти (2021)), which is the State Standard for Early Childhood Education of Ukraine, implemented through programs and educational and methodological support, approved by the Ministry of Education and Science of Ukraine.

The updated Law of Ukraine "On Education" (2017) and the guidelines of the Ministry of Education and Science of Ukraine $(2018,2019)$ guarantee every institution of education and early childhood, in particular, academic, organizational, financial and personnel autonomy, and the head - in the management of the institution, making decisions on organization of its work.

In particular, according to the Law of Ukraine "On Preschool Education" (2001) for the work with children of early and preschool age, each institution was granted a number of rights that were not previously. One of them is the development of an educational program of the institution, which ensures that the level of early childhood education meets the requirements of The Basic Component of Preschool Education (Ukraine). In addition, teaching staff of institutions are empowered to determine on their own what existing comprehensive and partial programs work. It is valuable that the institution can use several comprehensive and partial programs, in accordance with which the teachers plan educational work with children. The result of this choice is discussed and approved by the teachers' meeting. Consistent with this plan is another document that we have developed. This is an Exemplary Statute on the Methodical Office of the Early Childhood Educational Institution (2018). The main tasks of the methodical office include the tasks of 
accumulating in the methodical office of the institution and informing teachers about programs, novelties of methodological literature and providing assistance in their use.

The following documents we have developed were letters from the Ministry of Education and Science of Ukraine $(2018,2019)$ on the lists of educational literature recommended by the Ministry of Education and Science of Ukraine for use in educational institutions in general and early childhood educational institutions, in particular. These annual letters are issued to inform the pedagogical public about the list of programs and manuals recommended for use in organizing the educational process during the school year. Thus, in the 2019-2020 academic year, 11 comprehensive programs, 26 partial, over 20 manuals and over 200 titles of methodological literature were recommended for use in early childhood educational institutions in Ukraine.

The content of the empirical part of the study was conducting an experiment. At this stage of the experiment, our tasks were: to study the level of awareness of early childhood teachers and practitioners with the variety of educational programs for early childhood educational institutions in Ukraine and the right to choose these programs, to study the level of providing of early childhood educational institutions with these programs, and to study the need for methodological support in the selection of educational programs for early childhood educational institutions.

The main method of our research is observation, we used it in the institutions of the first link of the system of education when organizing and conducting various types of practices and practical classes with students. The results of long and selective observations gave us the reasons to maintain that the vast majority of early childhood educational institutions have a clear system in the use of educational programs recommended by the Ministry of Education and Science of Ukraine in the organization of the educational process. Teachers use different programs in different early childhood educational institutions. Some establishments use one or two comprehensive and several partial programs.

The next method we used is observing the organization of methodological work with early childhood teachers regarding the use of different educational programs. The results of the observations give reasons to affirm that only single seminars, master classes are devoted 
to this issue. In our opinion there are several reasons for this. This is the lack of centralized provision of preschool institutions with variational and partial programs, which leads to the acquisition of programs and methodological support to them by the teachers themselves at their own expense; low level of technical support of early childhood educational institutions for the use of digitized program texts (at best, the presence of one or two stationary computers in the offices of the administration for the whole institution); low level of awareness of the content of comprehensive and partial programs of principals and methodologists of early childhood educational institutions, that is, concentration on work on one program; frequent instances of reluctance of the administration of institutions to convert members of the staff from one to another, or other programs, etc., as reported by $30 \%$ of respondents.

The selective discussions and anonymous questionnaires with the principals and methodologists of early childhood educational institutions, conducted by us, confirmed the great interest in the right to choose from the list of educational programs, both comprehensive and partial, recommended by each staff. Most of the respondents said that they were not ready for the process of creating their own programs. The most accurate were the statements of directors and teachers-methodologists of early childhood educational institutions, recorded during our discussions: "Let the programs be written by scientists and our business is to work with children", "There are some creative educators in our institution who could create a small program based on their experience, but they need help ... Who will provide it?", "If we are still to start writing programs, when will we execute our duties?" etc.

In parallel with the sample interviews, we surveyed heads of preschool educational institutions (Fig. 1.)..

Are you personally ready to create an educational program of the institution together with the members of the preschool educational institution staff?
State the reasons for your negative attitude to the possibility and right to create an educational program of your institution
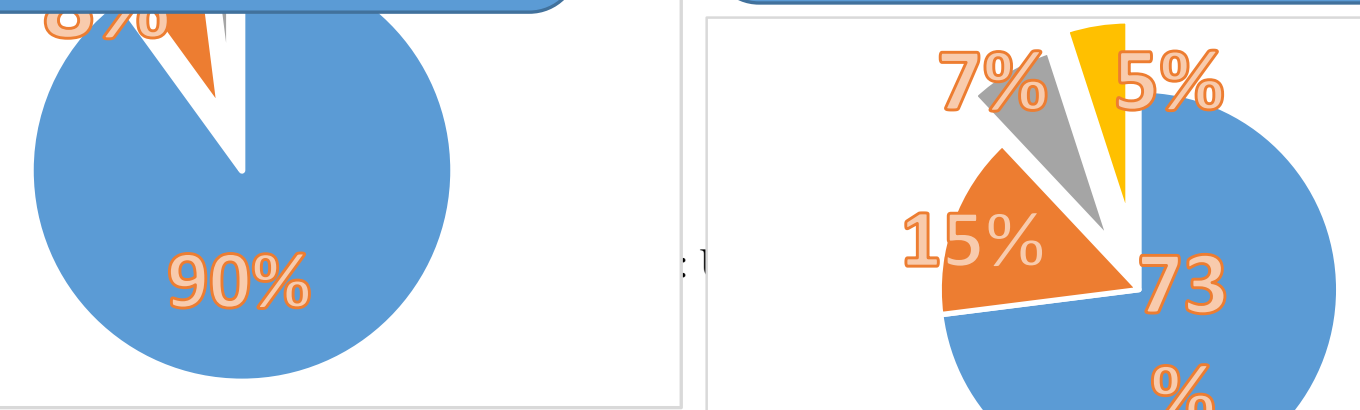
Fig. 1. Results of the survey of early childhood teachers

The results of our anonymous questionnaire were as follows: To the first question "Are you personally ready to create an educational program of the institution together with the members of the preschool educational institution staff?" $90 \%$ of respondents gave a negative answer, $8 \%$ - expressed a desire for this work, $2 \%$ - refused to answer. To the second question "State the reasons for your negative attitude to the possibility and right to create an educational program of your institution" $73 \%$ of respondents said they were not ready for this work, $15 \%$ - wrote about not understanding why it is needed, $7 \%$ - said that scientists should do it, not practitioners, $5 \%$ - refused to answer.

The next method we used is anonymous questionnaire of teaching staff of early childhood educational institutions. In all educational institutions of the first link that were covered by the survey, teachers were asked several questions for the research. The results of the survey were as follows.

$75 \%$ of the respondents answered the first question in the affirmative, but on the assumption of providing with them. $20 \%$ of teachers gave a negative answer. Among the reasons was the low level of information support, the long-standing habit of working in one comprehensive program, the unwillingness to improve professionally compared to other colleagues. $5 \%$ refused to give a direct answer (Fig. 2.). 


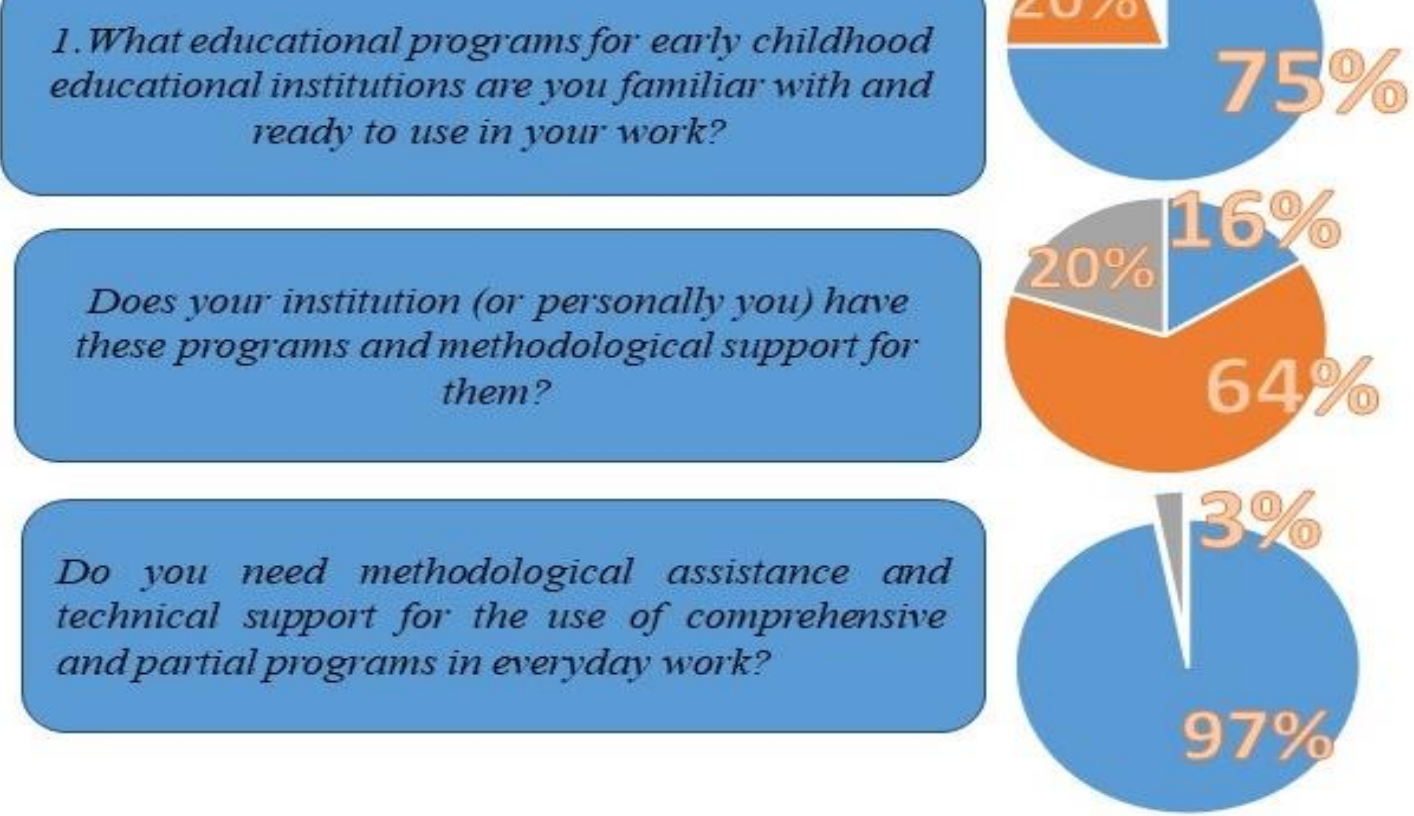

Fig. 2. Results of the survey of early childhood teachers

Only $16 \%$ of early childhood teachers up to 30 years old answered yes to the second question. $64 \%$ of teachers admitted that they did not understand the question and had never heard of it. $20 \%$ refused to give a direct answer (Fig. 2.).

$97 \%$ of teachers answered yes to the third question in all early childhood educational institutions. 3\% refused to give a direct answer (Fig. 2.).

Our analysis of the conducted questionnaire gives grounds to confirm the readiness of the majority of teachers for the use of comprehensive and partial programs in the educational process and the desire to receive regular methodological help on this issue.

Thus, it can be concluded that most of teaching staff are ready to use in their work different comprehensive and partial programs, they are "open" to novelties in their work with children. However, they lack for the providing of these programs and their manuals, as well as regular on-site methodological support to explain the content and features of each specific program. This question will be the content of our further research.

The content of the next stage of our study was the development of providing early childhood education in the European Union with programs. To this effect, we have worked out and analyzed programs and state standards for early childhood education in Bulgaria, Lithuania, Great Britain, Switzerland, Germany, etc. 
Analysis of regulatory documents for the development of preschool children in European countries, in particular national standards for early childhood education of Bulgarian "State Educational Standards" (Държавни образователни стандарти, 2016), Lithuanian "General Early Childhood Education Program" (Priešmokyklinio ugdymo bendroji programa, 2014), English "Statutory framework for the early years foundation stage Setting the standards for learning, development and care for children from birth to five", the Swiss "Hereinafter referred to as standards "(Läroplan för förskolan, 2018) allowed us to make the following conclusions:

1. All systems of early childhood education recognize the uniqueness of childhood, educational work is based on a competent approach, and game is recognized as a leading activity in an early childhood educational institution.

2. In the state standards of early childhood education of these countries, work is carried out in different areas of development and learning (in Ukrainian - educational lines). Work on speech, social, physical, mathematical, artistic development is common to all programs, but each has several features.

The English programs highlight three main areas of development and learning communication and language, physical development, personal, social and emotional development. Familiarization of children with the social, natural and subject world and the acquisition of relevant competencies are highlighted in "The Basic Component of Preschool Education".

The Bulgarian "State Educational Standard" (Държавни образователни стандарти, 2016) details the artistic direction. It includes music, fine arts and design. Analyzing the content areas of work, we pay attention to the social and emotional development, which is present in all programs, but as a separate area, defined by English specialists. Much attention is paid to language learning in early childhood educational institution. The English and Ukrainian standards focus on the development of children's communicative and speaking skills.

3. In our opinion, it is a promising opportunity for teachers to create their own programs for the development of preschool children. Ukrainian "Basic Component of Preschool Education", Lithuanian "General Early Childhood Education Program", English 
Statutory Framework for the Early Years Foundation Stage Setting standards for learning, development and care for children from birth to five are state standards and should be the basis for educational work with children in early childhood education, regardless of the form of ownership. Lithuanian specialists propose "Guidelines for the Development of the Early Childhood Educational Institution Curriculum" (IkImokyklInIo ugdymo metodInès rekomendacIjos, 2015), which details for practitioners the features of planning, educational work, monitoring, ensuring consistency in the quality of work with children. Interesting is the experience of creating authoring programs for the Swiss Confederation, which preschool education is considered one of the best in Europe. It is a universally recognized assessment that has been built up over the decades, thanks to the traditions, quality of teaching and history of the kindergartens. Many followers of M. Montessori, R. Steiner, J. Pestalozzi and other famous educators worked here. Kindergartens in Switzerland are divided by nationality, namely: German, French-Italian and Swiss. The German cantons pay attention to the general development of children, while the FrancoItalian cantons prepare children for further education at schools, while the central cantons give children competences. There are different requirements for the content of work in early childhood educational institution in every region (canton) of the country. The concept of a "single program" for kindergartens is absent, as each institution develops its own program depending on its field of work.

A similar approach to the content of education, similar to the Swiss Confederation, has been chosen by Germany for the last few decades. In each of the 16 federal states of the country there are different requirements for the content of education in general and especially in early childhood education. Kindergartens of federal (state) subordination organize educational work with children by the standards. Private institutions organize their work depending on its direction (religious, trade union, care, health-improving, etc.). The norm for early childhood teachers is to create their own authoring program for working with children. In most institutions, on the basis of such a general program teachers make programs (roadmaps) for each child in the group, taking into account the individual characteristics of every child. Kindergarten management analyzes and evaluates 
the work of teachers, in accordance with the indicators, as each child moves on his /her road map and how the teacher helps in this.

However, in our opinion, specially designed programs for the development of preschool children are important and necessary for practitioners, since they detail the content and tasks of educational work with preschool children in accordance with state standards, based on scientific development and innovative experience, the choice of which remains the right of preschool teachers and parents.

Conclusions. The purpose of our study was to formulate our vision of programs for preschool educational institutions. For more than half a century, Ukrainian early childhood educational institutions have been working on a single program that has led to the emergence of a unitary preschool system. Not everything in it should be criticized. However, the only compulsory program has led to the emergence of establishing a single type of early childhood educational institutions with a single content, educational methods and requirements for its consequences.

This led to a simplification of the educational process, the daily routine, the style of relationships between early childhood teachers and children, the devaluation of creative attitude to work with children, psychological personal disorientation.

And today, in our opinion, the warnings of teachers and psychologists of the past have been taken into account regarding the negative impact of uniform programs "produced at the center" for public early childhood education. It is the recommendations for variant programs preschool educational institutions that have become a significant social, pedagogical and psychological guideline. And the right of teaching staff to create their own educational programs has become a display of faith and confidence in their own strength and creativity of preschool teachers.

The experience of European countries is valuable for improving the quality of Ukrainian early childhood education. The analysis of state standards and programs for preschool education shows that there are common views on the education of preschool children in the European educational space.

We consider it promising to further study quality assurance issues of education in European countries, trends, and factors that affect them. In our opinion, the study of 
effective interaction methods in the teaching staff of a preschool educational institution and the cooperation of teachers with parents of pupils deserve special attention.

\section{References}

Bielienka, H. V., Kovalenko, O. V. Shynkar, T. Yu. (2020) Yakist doshkilnoi osvity v Ukraini ta krainakh YeS: parametry vymiru ta metodychnyi suprovid [Quality of preschool education in Ukraine and EU countries: measurement parameters and methodical support] Pedahohika formuvannia tvorchoi osobystosti u vyshchii i zahalnoosvitnii shkolakh №72.T1. S. 33-39. https://doi.org/10.32840/19925786.2020.72-1.6 [in Ukraine]

Pirozhenko, T. O. (2018) Yakist doshkilnoi osvity: suchasna sytuatsiia ta pohliad u perspektyvu [The quality of preschool education: the current situation and the view in the perspective] Aktualni problemy psykholohii: zbirnyk naukovykh prats Instytutu psykholohii imeni H.S. Kostiuka NAPN Ukrainy. Kharkiv. Psykholohiia rozvytku doshkilnyka 14. 6-27. [in Ukraine]

Vaskivska, O. H., Palamar, S. P., Kondratiuk, S. G., Zhelanova, V. V. (2018) Psychodidactic determinants of the development of children of preschool age. Wiadomości Lekarskie. c. 1207-1214. ISSN 0043-5147

Shchodo metodychnykh rekomendatsii do onovlenoho Bazovoho komponenta doshkilnoi osvity (Derzhavnoho standartu doshkilnoi osvity) (2021) [Regarding methodical recommendations to the updated Basic component of preschool education (State standard of preschool education) (2021)] / Lyst MON Ukrainy № 1/9-148 vid 16.03.2021 r. - Rezhym dostupu: https://mon.gov.ua/ua/npa/shodo-metodichnihrekomendacij-do-onovlenogo-bazovogo-komponenta-doshkilnoyi-osviti

[in Ukraine]

Дьржавни образователни стандарти НАРЕДБА № 5 от 03.06 .2016 г. за предучилищното образование Обн. - ДВ, бр. 46 от 17.06.2016 г., в сила от 01.08.2016 г. Издадена от министъра на образованието и науката (2016) https://www.mon.bg/bg/100104

IkImokyklInIo ugdymo metodInès rekomendacljos https://www.smm.lt/uploads/documents/tevams_ugdymo_planai/knyga\%20\%20rek omendacijos.pdf

Läroplan för förskolan, (2018) https://www.skolverket.se/download/18.6bfaca41169863 e6a65d5aa/1553968116077/pdf4001.pdf

Priešmokyklinio Ugdymo Bendroji Programa, https://www.smm.lt/uploads/documents/Prie\%C5\%A1mokyklinio\%20ugdymo\%20 bendroji\%20programa(3).pdf

Statutory framework for the early years foundation stage Setting the standards for learning, development and care for children from birth to five (2017) https://assets.publishing.service.gov.uk/government/uploads/system/uploads/attachm ent_data/file/596629/EYFS_STATUTORY_FRAMEWORK_2017.pdf

Shynkar, T., Bielienka A., Kovalenko, O. (2020) ICT as a Tool for Improving the Quality of Methodical Work in the First Link of the System of Education CEUR Workshop 
Proceedings of the 16th International Conference on ICT in Education, Research and Industrial Applications. Integration, Harmonization and Knowledge Transfer. Volume I: Main Conference Kharkiv, Ukraine, October 06-10, 2020.. ISSN 16130073

\section{Літіратура}

Бєлєнька Г. В., Коваленко О. В. Шинкар Т. Ю. (2020) Якість дошкільної освіти в Украӥні та країнах $С$ : параметри виміру та методичний супровід Педагогіка формування творчої особистості у вищій і загальноосвітній школах №72.Т1. С. 33-39.DOI https://doi.org/10.32840/1992-5786.2020.72-1.6

Піроженко Т.О.(2018) Якість дошкільної освіти: сучасна ситуація та погляд у перспективу. Актуальні проблеми психології: збірник наукових праць Інституту психології імені Г.С. Костюка НАПН України. Харків. Том. IV: Психологія розвитку дошкільника. Випуск 14. С. 6-27.

Щодо методичних рекомендацій до оновленого Базового компонента дошкільної освіти (Державного стандарту дошкільної освіти) (2021) / Лист МОН України № 1/9-148 від 16.03.2021 p. URL: https://mon.gov.ua/ua/npa/shodo-metodichnihrekomendacij-do-onovlenogo-bazovogo-komponenta-doshkilnoyi-osviti (дата звернення 24.04.2021 р.).

Vaskivska O. H., Palamar S. P., Kondratiuk S. G., Zhelanova V. V. Psychodidactic determinants of the development of children of preschool age. Wiadomości Lekarskie. c. 1207-1214. ISSN 0043-5147

Държавни образователни стандарти НАРЕДБА № 5 от 03.06 .2016 г. за предучилищното образование Обн. - ДВ, бр. 46 от 17.06.2016 г., в сила от 01.08.2016 г. Издадена от министьра на образованието и науката (2016) URL: https://www.mon.bg/bg/100104 (дата звернення: 08.05.2021)

IkImokykIInIo ugdymo metodInès rekomendacIjos

https://www.smm.lt/uploads/documents/tevams_ugdymo_planai/knyga\%20-

$\% 20$ rekomendacijos.pdf

Läroplan för

förskolan

(2018)

URL:

https://www.skolverket.se/download/18.6bfaca41169863e6a65d5aa/1553968116077 /pdf4001.pdf

Priešmokyklinio Ugdymo Bendroji Programa (2014) URL: https://www.smm.lt/uploads/documents/Prie\%C5\%A1mokyklinio\%20ugdymo\%20 bendroji\%20programa(3).pdf (дата звернення: 08.05.2021)

Statutory framework for the early years foundation stage Setting the standards for learning, development and care for children from birth to five (2017) https://assets.publishing.service.gov.uk/government/uploads/system/uploads/attachm ent_data/file/596629/EYFS_STATUTORY_FRAMEWORK_2017.pdf （дата звернення: 08.05.2021)

Shynkar T., Bielienka A., Kovalenko O. (2020) ICT as a Tool for Improving the Quality of Methodical Work in the First Link of the System of Education CEUR Workshop Proceedings of the 16th International Conference on ICT in Education, Research and Industrial Applications. Integration, Harmonization and Knowledge Transfer. 
Volume I: Main Conference Kharkiv, Ukraine, October 06-10, 2020.. ISSN 16130073

\title{
ПРОГРАММНОЕ ОБЕСПЕЧЕНИЕ ДОШКОЛЬНОГО ОБРАЗОВАНИЯ: УКРАИНСКИЙ И ЕВРОПЕЙСКИЙ ОПЫТ
}

\author{
Елена Коваленко, кандидат педагогических наук, доцент, \\ доцент кафедры дошкольного образования, Педагогического института, \\ Киевский Университет имени Бориса Гринченко, \\ ул. Бульварно-Кудрявская 18/2, г. Киев, Украина, o.kovalenko@kubg.edu.ua
}

Елена Литиченко, кандидат педагогических наук, старший преподаватель кафедры дошкольного образования Педагогического института,

Киевский Университет имени Бориса Гринченко,

ул. Бульварно-Кудрявская 18/2, г. Киев, Украина, o.litichenko@kubg.edu.ua

B статье представлень результать теоретического исследования нормативных документов дошкольного образования Украины и стран Европейского Союза, изучено мнение авторитетных ученых по вопросу программного обеспечения дошкольного образования Украины. Акиентировано внимание на том, что качественное развитие детей дошкольного возраста зависит от возможности педагогов обеспечить индивидуальное развитие каждого ребенка, поэтому вопрос создания качественной программы образования особенно актуален. На основе анализа дискуссионных вопросов, связанных с программным обеспечением учреждений дошкольного образования, осуществлено эмпирическое исследование осведомленности педагогов-практиков дошкольных учреждений с разнообразием образовательных программ для дошкольных учреждений в Украине, правом их выбора и создания собственных. Рассмотрен опыт Болгарии, Литвы, Великобритании, Швейцарии. Результаты анализа государственных стандартов и программ дошкольного образования показывают, что существуют общие взгляды на воспитание детей дошкольного возраста в европейском образовании. В этой статье авторы доказывают важность и необходимость возможности для учителей создавать собственные программы для развития детей дошкольного возраста.

Ключевые слова: выбор программ; государственных стандартов дошкольного образования; дошкольное образование; комплексные программы; парииальные программы; образовательные программы для детей дошкольного возраста.

\section{ПРОГРАМНЕ ЗАБЕЗПЕЧЕННЯ ДОШКІЛЬНОЇ ОСВІТИ: УКРАЇНСЬКИЙ ТА ЄВРОПЕЙСЬКИЙ ДОСВІД}

Коваленко Олена, кандидат педагогічних наук, доцент, доцент кафедри дошкільної освіти Педагогічного інституту, 
Київський університет імені Бориса Грінченка, вул. Бульварно-Кудрявська 18/2, м. Київ, Україна, o.kovalenko@kubg.edu.ua

Літіченко Олена, кандидат педагогічних наук, старший викладач кафедри дошкільної освіти Педагогічного інституту, Київський університет імені Бориса Грінченка, вул. Бульварно-Кудрявська 18/2, м. Київ, Україна, o.litichenko@kubg.edu.ua

У статті представлені результати теоретичного опраџювання нормативних документів дошкільної освіти Украӥни та краӥн Свропейського Союзу, вивчено думку авторитетних учених з питання програмного забезпечення дошкільної освіти України. Закиентувано увагу на тому, що якісний розвиток дітей дошкільного віку залежить від можливості педагогів забезпечити індивідуальний розвиток кожної дитини, тому питання створення якісної програми освіти особливо актуальне. На основі аналізу дискусійних питань пов'язаних з програмним забезпеченням закладів дошкільної освіти, здійснено емпіричне дослідження обізнаності педагогівпрактиків дошкільних закладів з різноманітністю освітніх програм для дошкільних закладів в Україні, правом їх вибору та створення власних. Розглянуто досвід Болгарії, Литви, Велико Британії, Швейцарії. Результати аналізу державних стандартів та програм дошкільної освіти показують, що існують спільні погляди на виховання дітей дошкільного віку в європейській освіті. У иій статті автори доводять важливість і необхідність можливості для вчителів створювати власні програми для розвитку дітей дошкільного віку.

Ключові слова: вибір програм; державні стандарти дошкільної освіти; дошкільна освіта; комплексні програми; париіальні програми; освітні програми дітей дошкільного віку. 